\title{
Hubungan Kompetensi Profesional Guru dengan Minat Belajar Siswa Kelas IV Pada Mata Pelajaran Ilmu Pengetahuan Sosial di SD Islam Majanubil'ilmi Sukamaju Tahun Pelajaran 2016/2017"
}

\author{
Lalu Asriadi,Muhammad Musfiatul Wardi \\ Program Studi Pendidikan Guru Madrasah Ibtidaiyah Fakultas Agama Islam \\ Universitas Muhammadiyah Mataram \\ Jl. K.H. Ahmad Dahlan No. I Pagesangan - Mataram \\ Korespondensi Penulis: laluasriadiI5@gmail.com, musfetI4@gmail.com
}

\begin{abstract}
ABSTRAK
Kata Kunci : Kompetensi Profesional Guru, Minat Belajar Siswa
\end{abstract}

Berdasarkan hasil observasi awal yang dilakukan pada tanggal 19 Maret 2017, peneliti menemukan bahwa kompetensi profesional guru mata pelajaran Ilmu Pengetahuan Sosial di SD Islam Majanubil'ilmi ternyata masih belum optimal, ini terlihat dari kurangnya penguasaan materi pelajaran oleh guru, metode dan media pembelajaran yang digunakan masih monoton, kurang menguasai kelas yang ditandai dengan kurang kondusifnya suasana di dalam kelas serta kualifikasi guru yang tidak sesuai. ${ }^{28}$ Sementara itu, berkaitan dengan minat belajar siswa kelas IV pada mata pelajaran Ilmu Pengetahuan Sosial ternyata masih kurang. Hal ini terlihat dari masih adanya siswa yang mengantuk pada saat proses belajar mengajar berlangsung, saling mengganggu antar siswa, tidak memperhatikan penjelasan guru di depan kelas, sebagian siswa tidak memiliki catatan lengkap. Berbagai upaya telah dilakukan untuk dapat meningkatkan minat belajar siswa, diantaranya dengan pemberian pelajaran tambahan, menyediakan LKS yang dilengkapi dengan sejumlah soal-soal latihan, tetapi hasilnya masih belum maksimal. Kenyataan tersebut dapat diduga penyebabnya antara lain, siswa kurang memahami konsep pembelajaran Ilmu Pengetahuan Sosial, siswa kurang termotivasi menyelesaikan tugas-tugas di rumah, minat baca siswa masih rendah, siswa jarang berani bertanya pada saat proses belajar mengajar. Penelitian ini bertujuan untuk mengetahui (I) Gambaran kompetensi profesional guru di SD Islam Majanubil'ilmi (2) Gambaran minat belajar siswa di SD Islam Majanubil'ilmi (3) Hubungan antara kompetensi profesional guru dengan minat belajar siswa kelas IV pada mata pelajaran IPS di SD Islam Majanubil'ilmi Sukamaju Lombok Timur. Populasi penelitian ini adalah siswa kelas IV di SD Islam Majanubil'ilmi yang berjumlah I9 orang. Jenis penelitian yang dilakukan termasuk dalam jenis penelitian kuantitatif dengan pendekatan korelasional. Teknik pengumpulan data menggunakan observasi, angket dan dokumentasi. Sedangkan instrument yang digunakan dalam penelitian ini adalah instrument angket. Berdasarkan hasil penelitian, menunjukkan bahwa kompetensi profesional guru dan minat belajar siswa berada pada kategori sedang dan tidak terdapat hubungan yang positif dan signifikan antara kompetensi profesional guru dengan minat belajar siswa, hal ini dapat dibuktikan dari hasil analisis menggunakan rumus Pearson Poduct Moment dengan menggunakan bantuan Microsoft Excel. Diperoleh hasil $\mathrm{r}$ hitung sebesar 0,262. Jika nilai $\mathrm{r}$ hitung ini dikonsultasikan dengan nilai $\mathrm{r}$ tabel untuk taraf signifikan $5 \%$ atau $\mathrm{I} \%$ dengan $\mathrm{N}=\mathrm{I}$, diperoleh $\mathrm{r}$ tabel $=0,456$ maupun taraf signifikan $\mathrm{I} \%$ diperoleh 0,575. Karena $\mathrm{r}$ hitung $\leq \mathrm{r}$ tabel untuk kesalahan $5 \%(0,262 \leq 0,456)$, maka dapat disimpulkan bahwa tidak terdapat hubungan yang positif antara kompetensi profesional guru dengan minat belajar siswa kelas XI pada mata pelajaran IPS di SD Islam Majanubil'ilmi. Sehingga hipotesis yang diajukan ditolak.

${ }^{28}$ Observasi Awal, pada tanggal 19 Maret 2017. 


\section{PENDAHULUAN}

Kompetensi profesional guru adalah kemampuan guru dalam penguasaan terhadap materi pelajaran dan kemampuan guru dalam pengelolaan pembelajaran (pemahaman terhadap peserta didik, perencanaan pelaksanaan pembelajaran, penguasaan metode dan media pembelajaran serta penilaian hasil belajar).

Minat sangat diperlukan dalam proses belajar, sebab seseorang yang tidak mempunyai minat dalam belajar tidak akan mungkin melakukan aktivitas belajar. Hal ini merupakan pertanda bahwa sesuatu yang akan dikerjakan itu tidak menyentuh kebutuhannya. Segala sesuatu yang menarik minat orang lain belum tentu menarik minat orang tertentu selama sesuatu itu tidak bersentuhan langsung dengan kebutuhannya. Secara sederhana, minat adalah kecendrungan dan kegairahan yang tinggi terhadap sesuatu. Kondisi belajar mengajar yang efektif adalah minat dan perhatian dalam belajar. Minat merupakan sumber motivasi yang mendorong untuk melakukan apa yang mereka inginkan bila mereka bebas memilih. ${ }^{29}$ Sukardi, mengemukakan bahwa "minat belajar adalah suatu kerangka mental yang terdiri dari kombinasi gerak perpaduan dan campuran dari perasaan, perasangka, cemas dan kecendrungankecendrungan lain yang bisa mengarahkan individu kepada suatu pilihan tertentu". ${ }^{30}$

Kedua pendapat mengenai minat belajar ini, dapat difahami bahwa minat belajar ialah aspek psikologi seseorang yang menampakkan dirinya dalam beberapa gejala seperti: gairah, keinginan, perasaan suka untuk melakukan proses perubahan tingkah laku melalui berbagai kegiatan yang meliputi mencari pengetahuan dan pengalaman. Dengan kata lain, minat belajar adalah keinginan, rasa suka yang ditunjukkan melalui keantusiasan dan keaktifan dalam belajar.

Berdasarkan hasil observasi awal yang dilakukan pada tanggal I9 Maret 2017, peneliti menemukan bahwa kompetensi

29 Elizabert B. Hurlock, Perkembangan Anak, Jilid 2(Jakarta: Erlangga, I989), h. I I4.

30 Sukardi, Bimbingan dan Penyuluhan (Surabaya: Usaha Nasional, I987), h. 25. profesional guru mata pelajaran Ilmu Pengetahuan Sosial di SD Islam Majanubil'ilmi ternyata masih belum optimal, ini terlihat dari kurangnya penguasaan materi pelajaran oleh guru, metode dan media pembelajaran yang digunakan masih monoton, kurang menguasai kelas yang ditandai dengan kurang kondusifnya suasana di dalam kelas serta kualifikasi guru yang tidak sesuai. ${ }^{31}$

Sementara itu, berkaitan dengan minat belajar siswa kelas IV terhadap mata pelajaran Ilmu Pengetahuan Sosial ternyata masih kurang. Hal ini terlihat dari masih adanya siswa yang mengantuk pada saat proses belajar mengajar berlangsung, saling mengganggu antar siswa, tidak memperhatikan penjelasan guru di depan kelas, sebagian siswa tidak memiliki catatan lengkap. Berbagai upaya telah dilakukan untuk dapat meningkatkan minat belajar siswa, diantaranya dengan pemberian pelajaran tambahan, menyediakan LKS yang dilengkapi dengan sejumlah soal-soal latihan, tetapi hasilnya masih belum maksimal. Kenyataan tersebut dapat diduga penyebabnya antara lain, siswa kurang memahami konsep pembelajaran Ilmu Pengetahuan Sosial, siswa kurang termotivasi menyelesaikan tugas-tugas di rumah, minat baca siswa masih rendah, siswa jarang berani bertanya pada saat proses belajar mengajar.

Peneliti berasumsi bahwa kompetensi profesional guru memiliki hubungan yang positif dengan minat belajar siswa. Oleh karena itu, peneliti merasa tertarik untuk melakukan penelitian dengan judul "Hubungan Kompetensi Profesional Guru dengan Minat Belajar Siswa Kelas IV pada Mata Pelajaran Ilmu Pengetahuan Sosial (IPS) di SD Islam Majanubil'ilmi Sukamaju Lombok Timur Tahun Pelajaran 2016/2017”. Adapun rumusan masalah penelitian ini adalah: (1) Bagaimana gambaran kompetensi profesional guru di SD Islam Majanubil'ilmi Sukamaju Lombok Timur? (2) Bagaimana gambaran minat belajar siswa di SD Islam Majanubil'ilmi Sukamaju Lombok Timur? (3) Adakah hubungan antara kompetensi

31 Observasi Awal, pada tanggal I9 Maret 
profesional guru dengan minat belajar siswa kelas IV pada mata pelajaran IPS di SD Islam Majanubil'ilmi Sukamaju Lombok Timur?.adapun kontribusi penelitian ini adalah (1) Memberikan gambaran tentang kompetensi profesional guru di SD Islam Majanubil'ilmi Sukamaju Lombok Timur (2) Memberikan gambaran tentang minat belajar siswa di SD Islam Majanubililmi Sukamaju Lombok Timur (3) Untuk mengukur hubungan antara kompetensi profesional guru dengan minat belajar siswa kelas IV pada mata pelajaran IPS di SD Islam Majanubil'ilmi Sukamaju Lombok Timur

\section{METODE}

Dalam penelitian ini, metode yang digunakan adalah metode penelitian kuantitatif. Penelitian kuantitatif adalah suatu proses menemukan pengatahuan yang menggunakan data berupa angka sebagai alat menemukan keterangan mengenai apa yang ingin diketahui. Pada umumnya penelitian kuantitatif dapat dijelaskan dalam bentuk dugaan deskriptif.

Adapun penelitian ini merupakan penelitian korelasional yaitu "salah satu teknik statistik yang digunakan untuk menganalisis hubungan antara variabel terikat dan variabel bebas yang bersifat kuantitatif'.32 Metode kuantitatif bertumpu sangat kuat pada pengumpulan data berupa angka hasil pengukuran. Karena itu data yang terkumpul harus diolah secara statistik agar dapat ditafsirkan dengan baik. Penggunaan data kuantitatif pada dasarnya diperlukan untuk memperoleh ketepatan relatif atau lebih mendekati dengan eksak. Data kuantitatif yang penyajiannya dalam bentuk angka yang secara sepintas lebih mudah untuk diketahui mampu untuk membandingkan satu dengan yang lain. Populasi dalam penelitian ini adalah siswa kelas IV di SD Islam Majanubil'ilmi Sukamaju Lombok Timur yang berjumlah I9 siswa.

32 Alfira, Statistik Penelitian, h. 73.
Tabel 3.I Sebaran Banyak Siswa Kelas IV di SD Islam Majanubil'ilmi Sukamaju Lombok Timur 33

\begin{tabular}{|l|l|l|l|l|}
\hline \multirow{2}{*}{ No } & \multirow{2}{*}{ K } & \multicolumn{2}{|c|}{$\begin{array}{c}\text { Jenis } \\
\text { Kelamin }\end{array}$} & \multirow{2}{*}{ Jumlah } \\
\cline { 3 - 4 } & elas & L & P & Iswa \\
\hline I & \multirow{2}{*}{ XI } & 9 & IO & I9 \\
\hline
\end{tabular}

Adapun instrumen atau alat yang digunakan dalam mengumpulkan data tersebut antara lain sebagai berikut:

I. Angket atau kuesioner

Angket (kuesioner) merupakan "sejumlah pertanyaan tertulis yang digunakan untuk memperoleh informasi dari responden".34 Kuesioner yang digunakan peneliti adalah kuesioner tertutup yaitu memberikan pertanyaan dengan alternatif jawaban yang telah disediakan dengan jumlah soal sebanyak 24 soal untuk variabel kompetensi profesional guru dan 24 soal untuk variabel minat belajar siswa. Jawaban alternatif $\mathrm{A}$ diberi skor 3, alternatif B diberi skor 2, alternatif C diberi skor I untuk pertanyaan yang bersifat positif dan jawaban alternatif A diberi skor I, alternatif B diberi skor 2, dan alternatif $\mathrm{C}$ diberi skor 3 untuk pertanyaan yang bersifat negatif. Sesuai dengan pedoman yang dikemukakan di atas, maka dapat dikembangkan kisi-kisi instrumen penyusunan angket tentang kompetensi profesional guru dan minat belajar siswa.

\section{Uji Validitas}

Validitas suatu instrumen menunjukkan tingkat ketetapan suatu instrument untuk mengukur apa yang harus diukur.35 Hasil penelitian yang valid bila terdapat kesamaan antara data yang terkumpul dengan data yang sesungguhnya terjadi pada obyek yang diteliti. Validitas suatu instrumen menunjukan suatu alat ukur yang dapat mengukur sejauh mana kebenaran alat itu untuk mengukur suatu yang diperlukan atau seberapa kesahihannya. Jenis validitas pada penelitian ini adalah validitas

${ }^{33}$ Dokumentasi, Lapor Bulan Madrasah Tahun Pelajaran 2016/20I7. Dikutip Tanggal 24 Mei 2017. Dari Bagian Tata Usaha.

34 Suharsimi Arikunto, Prosedur Penelitian suatu Pendekatan Praktis (Jakarta: Rineka Cipta, 2006), h. I5I.

${ }^{46}$ Alfira, Statistika Penelitian, h. 58. 
internal. Validitas internal terdiri validitas isi dan validitas konstruk. Validitas internal adalah pengujian validitas yang dilakukan dengan menelaah butir instrumen dengan teori dan meminta pertimbangan ahli (expert judgement)..

Sebuah instrumen dikatakan valid apabila dapat mengungkapkan data dari variabel yang diteliti secara tepat. Uji validitas dilakukan dengan menggunakan Korelasi Pearson Product Moment. Dengan rumus:

$$
\begin{aligned}
& \mathrm{r} \sum_{i=1}^{n} X_{i} Y_{i}-\left(\sum_{i=1}^{n} X_{i}\right)\left(\sum_{i=1}^{n} Y_{i}\right) \\
& \sqrt{\left(n \sum_{i=1}^{n} X_{i}^{2}-\left(\sum_{i=1}^{n} X i\right)^{2}\right)\left(n \sum_{i=1}^{n} Y_{i}^{2}-\left(\sum_{i=1}^{n} Y i\right)^{2}\right.} \\
& \quad \text { dengan: } \\
& n \quad=\text { Banyak responden } \\
& \quad X_{j i}=\text { Skor item/ butir ke- } j \text { responden ke- } i \\
& Y_{i}=\text { Skor total tiap responden }
\end{aligned}
$$

Jika nilai koefisien Pearson Product Moment ( $\mathrm{r}$ ) yang diperoleh adalah positif, kemungkinan butir yang diuji tersebut adalah valid. Walaupun hasilnya positif perlu untuk diuji signifikan atau tidaknya. Jika korelasi signifikan maka item instrumen adalah valid. Untuk menguji signifikansi nilai Pearson Product Moment berdasarkan hasil analisis ( $\mathrm{r}$ hitung) itu dibandingkan dengan nilai koefisien Pearson Product Moment ( $\mathrm{r}$ tabel) pada taraf signifikan $\alpha$ (biasanya dipilih 0,05 ) dan $\mathrm{n}=$ banyaknya data yang sesuai. Berikut ini keriteria keputusan bahwa instrumen butir ke- $i$ valid atau tidak.

Instrumen valid, jika $\mathrm{r}$ hitung $\geq \mathrm{r}$ tabel

Instrumen tidak valid, jika $\mathrm{r}_{\text {hitung }}<\mathrm{r}_{\text {tabel }}$.

Adapun pengklasifikasian kategori atau interpretasi dari nilai Product Moment Pearson yang diperoleh dapat di lihat pada Tabel 3.6.

Tabel 3.6 Interpretasi Nilai Product Moment Pearson. ${ }^{36}$

Uji Reliabilitas

Untuk menguji tingkat reliabilitas angket dapat dilakukan dengan menggunakan rumus Alfa Cronbach berikut ini:

$$
r_{i}=\frac{K}{K-1}\left\{1-\frac{\sum S_{i}}{S_{t}^{2}}\right\}
$$

Dimana:

$$
\mathrm{K} \text { = Banyak item instrumen }
$$

$\sum S_{i}=$ Jumlah varian skor item ke-i

Interval

Kategori

$$
\begin{aligned}
& 0,80 \leq \text { rhitung } \leq \mathrm{I}, 00 \\
& 0,60<\text { rhitung } \leq 0,80 \\
& 0,40<\text { rhitung } \leq 0,60 \\
& 0,20<\text { rhitung } \leq 0,40 \\
& 0,00<\text { rhitung } \leq 0,20 \\
& <\text { rhitung } \leq 0,00
\end{aligned}
$$$$
\text { Validitas Sangat Tinggi }
$$$$
\text { (Sangat Baik) }
$$$$
\text { Validitas Tinggi (Baik) }
$$$$
\text { Validitas Sedang (Cukup) }
$$$$
\text { Validitas Rendah (Kurang) }
$$$$
\text { Validitas Sangat Rendah }
$$$$
\text { (Jelek) }
$$

Tidak Valid

$$
S_{t}^{2}=\text { Varians skor total }
$$

Koefisiensi reliabilitas yang diperoleh diinterpretasikan sebagai berikut:

Tabel $3.7 \quad$ Interpretasi Koefisien Reliabilitas. ${ }^{37}$

Data yang akan dikumpulkan dengan lengkap, perlu menggunakan metode untuk mendapatkan data tersebut. Untuk itu peneliti menggunakan tiga metode pengumpulan data yaitu: Metode Observasi, Metode Angket, Metode Dokumentasi

Analisis disesuaikan dengan pendekatan yang digunakan, dalam penelitian ini diperoleh

\begin{tabular}{|c|l|}
\hline Interval & \multicolumn{1}{|c|}{ Kategori } \\
\hline $0,80<\mathrm{r}_{\mathrm{i}} \leq \mathrm{I}, 00$ & Reliabilitas Sangat Tinggi \\
$0,60<\mathrm{r}_{\mathrm{i}} \leq 0,80$ & Reliabilitas Tinggi \\
$0,40<\mathrm{r}_{\mathrm{i}} \leq 0,60$ & Relibilitas Sedang \\
$0,20<\mathrm{r}_{\mathrm{i}} \leq 0,40$ & Reliabilitas Rendah \\
$-0,00<\mathrm{r}_{\mathrm{i}} \leq 0,20$ & $\begin{array}{l}\text { Reliabilitas Sangat Rendah } \\
\text { (Tidak Reliabel) }\end{array}$ \\
\hline
\end{tabular}

data kuantitatif yaitu data yang direalisasikan dalam bentuk angka. Sementara angka yang diperoleh dari penelitian ini masih merupakan data mentah. Untuk memperoleh suatu kesimpulan, maka data tersebut harus diolah dengan menggunakan analisis statistik.

Sebelum melakukan penelitian atau memberikan perlakuan terhadap objek penelitian terlebih dahulu kita harus melakukan beberapa uji yang berhubungan dengan analisis akhir dari data penelitian.

Sebaran data menjadi satu asumsi yang menjadi syarat untuk menentukan jenis statistik apa yang akan dipakai dalam penganalisaan selanjutnya. ${ }^{38}$ Asumsi normalitas senantiasa

${ }^{36}$ Alfira, Statistika Penelitian, h. 59.

\footnotetext{
${ }^{37}$ Alfira, Statistika Penelitian, h. 62.

38 Ibid., h. 66.
} 
disertakan dalam penelitian pendidikan karena erat kaitannya dengan sifat dari subjek atau objek penelitian.

Uji normalitas dilakukan untuk mengetahui apakah data yang jadi inputan atau kedua objek penelitian terdistribusi normal atau tidak. Perhitungan uji normalitas dalam penelitian ini menggunakan bantuan aplikasi SPSS I6.0 for Windows.

Jika Signifikan (sig.) > 0,05 maka Ho diterima Jika signifikan (sig.) $<0,05$ maka $\mathrm{H}_{0}$ ditolak Uji Homogenitas

Dalam menguji kesamaan dua rata-rata, berulang kali diperlukan informasi tentang kesamaan variansi dari dua populasi agar proses pengujian dapat dilakukan. ${ }^{39}$ Uji homorgenesis dilakukan untuk mengetahui apakah data yang jadi imputan atau kedua objek penelitian bersifat homogen atau tidak berdasarkan nilai variansnya. Perhitungan uji homogenitas dalam penelitian ini menggunakan bantuan aplikasi SPSS I6.0 for Windows.

Analisis Pendahuluan

Analisis pendahuluan ini peneliti lakukan untuk mengetahui kompetensi profesional guru dan minat belajar siswa. Adapun rumusnya adalah sebagai berikut:

$$
\mathrm{P}=\frac{F}{N} \times 100 \%
$$

Keterangan :

$F=$ Jumlah frekuensi

$N=$ Jumlah of case (jumlah refrensi atau banyaknya individu)

$P=$ Persentase. ${ }^{40}$

Analisis Lanjutan

Analisis lanjutan yang digunakan peneliti adalah analisis korelasi Pearson Product Moment. Dengan menggunakan analisis ini, peneliti bermaksud untuk mengetahui hubungan kompetensi profesional guru dengan minat belajar siswa kelas IV pada mata pelajaran IPS di SD Islam Majanubil'ilmi Sukamaju Lombok Timur

Analisis korelasi merupakan salah satu teknik statistik yang digunakan untuk menganalisis hubungan antara variabel terikat dengan variabel bebas yang bersifat kuantitatif.
Analisis hubungan dilakukan dengan menghitung koefisiensi korelasi antar variabel. Koefisien korelasi yang biasa disimbolkan dengan $r$ merupakan angka yang menunjukkan arah dan kuatnya hubungan antar variabel. Arah dinyatakan dalam bentuk hubungan positif atau negative, sedangkan kuatnya hubungan dinyatakan dalam nilai koefisien korelasi. Variabel dikatakan saling berkorelasi jika perubahan suatu variabel diikuti dengan perubahan variabel yang lain. Kisaran koefisien korelasi diinterpretasikan pada tabel 3.8 berikut.

Tabel 3.8 Interpretasi Koefisien Korelasi. ${ }^{41}$ Adapun rumus metode analisis korelasi Pearson Product Moment yang dimaksud

\begin{tabular}{|c|l|}
\hline Interval & \multicolumn{1}{|c|}{ Kategori } \\
\hline & \\
$0,00-0,199$ & Sangat Rendah \\
$0,20-0,399$ & Rendah \\
$0,40-0,599$ & Sedang \\
$0,60-0,799$ & Kuat \\
$0,80-1,000$ & Sangat Kuat \\
& \\
adalah sebagai berikut: \\
$\mathrm{r}=\frac{n \sum X_{i} Y_{i}-\left(\sum X_{i}\right)\left(\sum Y_{i}\right)}{\left.\left.\sqrt{\left(n \sum X_{i}^{2}\right.}-(X i)^{2}\right) \sqrt{\left(n \sum Y_{i}^{2}\right.}-(Y i)^{2}\right)}$ \\
dengan:
\end{tabular}

$\mathrm{r}$ adalah koefisiensi korelasi antara variabel $\mathrm{X}$ dan variabel $Y$

$X_{i}$ adalah nilai data ke- i untuk kelompok variabel $X$

$Y_{i}$ adalah nilai data ke- $\mathrm{i}$ untuk kelompok variabel $\mathrm{Y}$

$\mathrm{n}$ adalah banyak data.

Dalam penelitian ini yang menjadi variabel independen atau yang mempengaruhi adalah kompetensi profesional guru yang dilambangkan dengan $\mathrm{X}$, sedangkan yang menjadi variabel dependen atau yang dipengaruhi adalah minat belajar siswa yang dilambangkan dengan $Y$.

\footnotetext{
39 Ibid., h. 69.

40 Anas Sudijono, Pengantar Statistik Pendidikan (Jakarta: Rajawali Press, I999), h.40.
} 


\section{HASIL PENELITIAN DAN PEMBAHASAN}

\section{A. Pengujian Hipotesis}

Adapun hipotesis yang diuji adalah hipotesis alternatif (Ha). Adapun bunyi hipotesis (Ha) adalah "Terdapat hubungan antara kompetensi profesional guru dengan minat belajar siswa kelas IV pada mata pelajaran IPS di SD Islam Majanubil'ilmi Sukamaju Lombok Timur". Uji hipotesis dalam penelitian ini menggunakan rumus Pearson Product Moment. Dari hasil perhitungan Pearson Product Moment diperoleh $\mathrm{r}$ hitumg sebesar 0,262. Jika nilai $\mathrm{r}$ hitumg ini dikonsultasikan dengan nilai $\mathrm{r}$ tabel untuk taraf signifikan $5 \%$ dengan $\mathrm{N}=\mathrm{I}$, diperoleh $\mathrm{r}_{\text {tabcl }}=0,456(5 \%)$. Karena $\mathrm{r}_{\text {hitung }} \leq \mathrm{r}_{\text {table }}$ untuk kesalahan $5 \%(0,262 \leq 0,456)$ maka hal ini berarti bahwa tidak ada korelasi antara kompetensi profesional guru dengan minat belajar siswa dan berada pada kategori rendah.

Dengan demikian, hipotesis yang menyatakan "Terdapat hubungan antara kompetensi profesional guru dengan minat belajar siswa kelas IV pada mata pelajaran IPS di SD Islam Majanubil'ilmi Sukamaju Lombok Timur" ditolak.

\section{B. Pembahasan}

Setelah melakukan berbagai pengujian statistik terhadap data yang diperoleh, peneliti mendapatkan gambaran mengenai kompetensi profesional guru dan minat belajar siswa. Adapun gambaran tersebut dapat terlihat dari hasil perhitungan dengan menggunakan teknik prosentase sebagai berikut:

Gambaran kompetensi profesional guru di SD Islam Majanubil'ilmi Sukamaju Lombok Timur menurut persepsi responden termasuk dalam kategori sedang, hal ini dapat terlihat dari hasil pengolahan angket variabel $\mathrm{X}$ dari $\mathrm{I} 9$ responden hampir seluruhnya menyatakan sedang yaitu sebanyak 9 orang (48\%), dan sisanya sebanyak 3 orang (16\%) menyatakan sangat tinggi, 5 orang (20\%) menyatakan tinggi dan 2 orang (10\%) menyatakan rendah. Hasil yang belum maksimal tersebut dapat dilihat dalam bulir angket yang memperoleh skor terendah (skor nomor 3 dan I8). Adapun pertanyaannya sebagai berikut: (nomor 3) Pada waktu menerangkan pelajaran, apakah guru Anda sering membaca atau melihat buku catatan yang dimiliki?, (nomor I8) Apakah guru Anda menggunakan media pada saat menjelaskan pokok bahasan akuntansi?.

Gambaran minat belajar siswa di SD Islam Majanubil'ilmi Sukamaju Lombok Timur menurut persepsi responden termasuk dalam kategori sedang, hal ini dapat terlihat dari hasil pengolahan angket variabel $Y$ dari 19 responden hampir seluruhnya menyatakan sedang yaitu sebanyak 8 orang (42\%), dan sisanya sebanyak 7 orang (37\%) menyatakan tinggi dan 4 orang $(21 \%)$ menyatakan rendah. Hasil yang belum maksimal tersebut dapat dilihat dalam bulir angket yang memperoleh skor terendah (skor nomor 7, 8 dan 16). Adapun pertanyaannya sebagai berikut: (nomor 7) Ketika Anda mendapat PR IPS, apakah Anda mengerjakannya?, (nomor 8) Apakah Anda merasa senang ketika guru IPS Anda memberikan tugas? (nomor I6) Apakah Anda didorong orang tua agar serius dalam mengikuti pembelajaran IPS?.

Berdasarkan hasil perhitungan koefisien korelasi product moment dengan menggunakan bantuan Microsoft Excel. Diperoleh hasil $\mathrm{r}$ hitung sebesar 0,262, hal ini menunjukkan bahwa variabel $\mathrm{X}$ (kompetensi profesional guru) dengan variabel $\mathrm{Y}$ (minat belajar siswa) mempunyai hubungan yang positif atau searah dengan kategori rendah yaitu terletak di antara $0,20-0,399$.

\section{Simpulan}

Merujuk pada hasil penelitian sebagaimana yang telah dijabarkan pada bab sebelumnya maka dapat disimpulkan bahwa: (I) Kompetensi profesional guru di SD Islam Majanubil'ilmi Sukamaju Lombok Timur menurut persepsi responden termasuk dalam kategori sedang. Hal ini dapat di lihat dari hasil pengolahan angket variabel $\mathrm{X}$ dari 19 responden hampir seluruhnya menyatakan sedang yaitu sebanyak 9 orang (48\%), dan sisanya sebanyak 3 orang ( $16 \%$ ) menyatakan sangat tinggi, 5 orang (20\%) menyatakan tinggi dan 2 orang (10\%) menyatakan rendah 
- (2) Minat belajar siswa di SD Islam Majanubil'ilmi Sukamaju Lombok Timur menurut persepsi responden termasuk dalam kategori sedang. Hal ini dapat di lihat dari hasil pengolahan angket variabel $Y$ dari 19 responden hampir seluruhnya menyatakan sedang yaitu sebanyak 8 orang (42\%), dan sisanya sebanyak 7 orang (37\%) menyatakan tinggi dan 4 orang (21\%) menyatakan rendah. (3) Berdasarkan hasil analisis menggunakan rumus Pearson Poduct Moment dengan menggunakan bantuan Microsoft Excel. Diperoleh hasil $\mathrm{r}$ hitung sebesar 0,262. Jika nilai $\mathrm{r}$ hitung ini dikonsultasikan dengan nilai $\mathrm{r}$ tabel untuk taraf signifikan $5 \%$ atau $1 \%$ dengan $\mathrm{N}$ $=19$, diperoleh $\mathrm{r}_{\text {tabel }}=0,456$ maupun taraf signifikan $\mathrm{I} \%$ diperoleh 0,575 . Karena $\mathrm{r}$ hitung $\leq$ r table untuk kesalahan $5 \%(0,262 \leq 0,456)$ maka dapat disimpulkan bahwa tidak terdapat hubungan yang positif antara kompetensi profesional guru dengan minat belajar siswa kelas IV pada mata pelajaran IPS di SD Islam Majanubil'ilmi Sukamaju Lombok Timur. Sehingga hipotesis yang diajukan ditolak.

\section{Referensi}

Elizabeth B. Hurlock. Perkembangan Anak, Jilid 2. jakarta : Erlangga, 1989.

Kurt Singer. Membina Hastat Belajar di Sekolah. Bandung: Remaja Karya, 1987.

Lukman Al-Hakim. Pedoman Penulisan

Skripsi. Mataram: IAIN Mataram, 2002.

Lalu Mukhtar, dkk. Profesi Keguruan. Mataram: Alam Tara Institute, 2012.

Moh. Uzer Usman. Menjadi Guru Profesional. Bandung: PT Rosda Karya, 2013.

......... Upaya Optimalisasi Kegiatan

Belajar Mengajar. Bandung: PT Remja Rosdakarya, I993.

Muhammad Nurdin. Kiat Menjadi Guru Profesional. Jogjakarta: Ar-Ruzz Media, 2008.

Ngalim Purwanto. Psikologi Pendidikan.

Bandung: Remaja Karya, 1987.

Oemar Hamalik. Pendidikan Guru Berdasarkan Pendekatan Kompetensi. Jakarta: Buni Aksara, 2002.

Riduan. Skala Pengukuran VariabelVariabel Penelitian. Bandung: Alfabeta, 2003.
Septi Rahayu, "Pengaruh Kompetensi Profesional Guru Terhadap Disiplin Kerja Guru SDN di Gugus Gatot Subroto Kecamatan Kutasari Kabupaten Purbalingga”. (Skripsi, UNY, Yogyakarta, 20I4).

Slameto. Belajar dan Faktor-Faktor yang Mempengaruhi. Jakarta: PT Rineka Cipta, 2013.

Sudarmanto. Tuntunan Metodologi Belajar. Jakarta: Grasindo, 1993.

Sugiyono. Metode Penelitian Kuantitatif dan Kualitatif dan $R \& D$. Bandung: Alfabeta, 2012.

Sukardi. Bimbingan dan Penyuluhan. Surabaya: Usaha Nasional, 1987.

Suharsimi Arikunto. Prosedur Penelitian suatu Pendektan Praktek. Jakarta: Bina Aksara, I99I.

....... Prosedur Penelitian suatu Pendektan Praktek Edisi Revisi V. Jakarta: PT Rineka Cipta, 2002.

...... Prosedur Penelitian suatu Pendektan Praktik. Jakarta: PT Rineka Cipta, 2006.

Suparlan. Menjadi Guru Efektif. Yogyakarta: Hikayat, 2005.

Supardi. Bacaan Cerdas Menyusun Skripsi. Yogyakarta: Kurnia Alam Semesta, 200I.

Tim Prima Pena. Kamus Besar Bahasa Indonesia. Jakarta: Gitamedia Press, $200 \mathrm{I}$. 